\title{
TENANT'S DEMAND FOR STRUCTURAL ATTRIBUTES IN RESIDENTIAL PROPERTIES: THE CASE OF EDE, NIGERIA
}

\author{
A. Chiwuzie ${ }^{1}$, D. I. Dabara², T. M. Adenipekun 3 , E. M. Prince ${ }^{4}$ and B. 0. \\ Ajiboye ${ }^{5}$ \\ 1,2,4,5 Department of Estate Management, Federal Polytechnic Ede, Nigeria \\ ${ }^{3}$ Department of Estate Management, Lagos State Polytechnic Ikorodu, Nigeria
}

\begin{abstract}
Structural attributes such as number and size of living rooms, bedrooms, toilet/ bathrooms and type of floor finishes have been identified as some of the factors that influence household's decisions when buying or renting a residential property. This study analysed the structural attributes of five categories of residential property in Ede, Nigeria with a view to providing information that will encourage investors to consider structural improvement that will enhance rental values. It examined among others tenant's desire for a particular attribute (and /or attribute's size); and tenant's willingness to pay more for the desired attribute(s). In order to determine responsiveness of willingness to pay, the study hypothesized that $90 \%$ of the respondent in each property types would express willingness to pay more for the desired attributes. Data for the study was collected through questionnaire administered to residential tenants in the study area. A total of 400 questionnaires were distributed out of which 278 were returned representing $69.5 \%$ response rate. Data collected were analysed using descriptive and inferential statistical tools such as percentile, bar charts, weighted mean score and Chi square. The result showed that larger bedroom was ranked very highly in terms of overall desire and would pay more for by all respondents. Beyond that, there were certain structural attributes that respondents across the property categories expressed willingness to pay more for. The chi-square result however revealed there is significant difference between "would pay more for" response and the expected proportion ( $p$ value < $.05)$ for the entire selected structural attribute in all categories of residential property. The study concluded that there is evidence to suggest that $90 \%$ of tenants in Ede did not express willingness to pay more for the desired structural attribute. The study recommended that investors in the residential property submarket should take cognizance of these when making decision on house design so as to have a product that appeals to tenant's expectations while ensuring maximization of return from investment.
\end{abstract}

Keywords: Nigeria, residential properties, structural attributes, tenant's demand, willingness to pay

\footnotetext{
1 okaugusta@yahoo.com

2 danieldabara44@gmail.com

3 martinsadenipekun@yahoo.com

${ }^{4}$ edithmbagwu@gmail.com

${ }^{5}$ bunmidele@gmail.com
}

A. Chiwuzie, D. I. Dabara, T. M. Adenipekun, E. M. Prince and B. O. Ajiboye (2019) Tenant's demand for structural attributes in residential properties: the case of Ede, Nigeria In: Laryea, S. and Essah, E. (Eds) Procs West Africa Built Environment Research (WABER) Conference, 5-7 August 2019, Accra, Ghana, 1063-1076 


\section{INTRODUCTION}

Residential property comprised several attributes; neighborhood, location and structural (Wilhelmsson, 2000; Aluko, 2011; Anthony, 2012). Each of these attributes exerts influences on the property and hence adds value to the property or otherwise reduces value of the property (Usman, 2016). Structural attributes that have been found to affect demand for residential properties include among others number of living rooms and bedrooms, size of both living and bedrooms, number of toilet and bathrooms, type and quality of floor finishes, level of interior and exterior decorations, perimeter fence and the available space (Odame, 2010; Anthony, 2012; Olayinka, Funsho and Ayotunde, 2013; Nishani, 2016). Okorie (2015) posited that these attributes constitute part of the basic social conditions that can define the quality of life and welfare of the people of residing in a particular property. Consequently, when households want to purchase or rent a residential unit, they have concerns towards the quality of property in terms of functional and live able contexts. Yam and Ismail (2008) found that preferences of housing consumers have changed from basic shelter to quality living environment. This suggests that tenants are becoming increasingly aware that the natures of a property or its structural attributes in terms of how well the property is built and designed have a profound impact on their productivity and general wellbeing. Hence, the need for residential properties to be designed in such a way to achieve convenience of care and enhance family living cannot be overemphasized.

Furthermore, studies have found that the presence of some structural attributes and or the sizes of structural attributes in a property determine the price of such a property. Anthony (2012) posited that if individuals get the amount and size of accommodation they want, they will be willing to pay higher value for it than they would pay for property with more or less the amount of accommodation they require. In fact, Okorie (2015) found that at least $58.65 \%$ of residential tenants expressed willingness to pay higher rent to have improved facilities incorporated in residential property. Buys et al. (2005) and Sitar and Krajnc (2008) similarly observed that consumers of residential properties were willing to pay more for properties with quality finishes. The implication is that the absence of quality structural attribute in a property will lead to a reduced rental value. Dabara et al., (2012a) opined that any decrease in rental values negatively affects the viability of landed property investment particularly investment in the residential property market.

The residential property market in Ede, Nigeria has evolved remarkably within the past few years. Thanks to the increased economic activities in the area occasioned by the establishment of higher educational institutions such as the Federal Polytechnic, Redeemers University and Adeleke University. This development has led to influx of people into the area resulting to high demand for residential properties both for owner-occupation and rental holdings. Rental holding as observed by Dabara, Olatoye and Okorie (2012b) is an essential component of a healthy housing system of a nation and predominates in most Nigeria's urban areas including Ede. This may not be unconnected to the fact that renting offers people a more affordable way of gaining access to accommodations (Amenyah and Fletcher, 2013). Furthermore, the diverse ethnic composition of people living in Ede town has impacted on both the types and quality of residential properties available 
in the market. The market which was hitherto dominated by tenement buildings is now housing a variety of residential properties types such as self-contained apartments, flats and duplexes with varying structural attributes. This study therefore tends to examine what tenants demand for in terms of structural attributes in residential properties. The term demand in economics connotes desire for a product which is backed with willingness to pay. Hence, understanding the structural attributes that tenants desire for in residential properties as well as their willingness to pay more for the desired attributes will assist the real estate investors in their bid to satisfy the needs of their customers while maximizing return from investments. More so, the knowledge of the demands of real estate consumers as well as their behavior will lead to better understanding of consumer dynamics and aid investment decisions in the real estate market (Gibler and Nelson, 2003).

In view of the above, the aim of the study was to examine tenant's demand for structural attributes in residential property in Ede, Nigeria with a view to providing information that will encourage investor to undertake structural improvements which will meet the expectations of tenants and at the same time attract higher rental values. The research questions include: What are the structural attributes (and /or attribute's size) in residential properties in Ede, Nigeria? What are the structural attributes (and /or attribute's size) that tenants desire for in residential properties in Ede? Are the tenants willing to pay more for the desired attribute(s) in the study area? Furthermore, in order to determine the tenants' responsiveness of willingness to pay more for the desired attributes, the study hypothesized that $90 \%$ of the respondent in each property categories would express willingness to pay more for the desired attributes.

\section{LITERATURE REVIEW}

Tan (2012) investigated the housing needs and preferences of first-time buyers in Kuala Lumpur with emphasis on certain characteristics of a dwelling such as the number of bathrooms, bedrooms, living rooms, kitchen, among others. Data collected was analyzed by means of regression model. The study revealed that major preference is often given to number of bedrooms.

Opoku and Abdul-Muhmin (2010) also examined housing preferences and attribute importance among low-income consumers in Saudi Arabia. The data was collected through a structured self-administered questionnaire. Relative importance index, chi- square and one-sample t-tests were employed in analyzing the data. The result revealed that number and size of bedrooms, size of living room, bathrooms, kitchen, availability of storage room, type of finishes, were among the important structural attributes that influence house preference among consumers in Saudi Arabia. This finding is consistent with the finding in Hurtubia, Gallay, and Bierlaire (2010). Al-Momani (2000) identified interior design, outdoor space functionality, kitchen size as among the key factors influencing Jordanian housing consumers.

Vahid (2015) on the other hand examined the perception on the priority of structural housing components from the point of view of house consumers in Malaysia. The study adopted the Non-structural fuzzy decision support system (NSFDSS) model as a tool for determining the perceived relative importance of the 
set decision criteria. Findings indicated that floor finishing was identified as among major structural housing attributes that influences the preference of house buyer's choice in Johor Bahru, Malaysia.

Table 1: summary of studies on house structural attributes and consumer's preferences

\begin{tabular}{|c|c|c|c|}
\hline Author (s) & Title & Structural Attributes Investigated & Findings \\
\hline $\begin{array}{l}\text { Vahid } \\
\text { Moghimi } \\
\text { Mahmud Bin } \\
\text { Mohd Jusan } \\
\text { (2015) }\end{array}$ & $\begin{array}{l}\text { Priority of } \\
\text { Structural } \\
\text { Housing } \\
\text { Attribute } \\
\text { Preferences: } \\
\text { identifying } \\
\text { Customer } \\
\text { Perception }\end{array}$ & $\begin{array}{l}\text { - Type, size and material of } \\
\text { doors and windows } \\
\text { - Presence and size of green area } \\
\text { - Space organization } \\
\text { - Space characteristics } \\
\text { - Kitchen position } \\
\text { - Bathroom position } \\
\text { - Size Living of room } \\
\text { - Number, size, location of } \\
\text { bedrooms } \\
\text { - Interior wall tiling } \\
\text { - Floor finishes }\end{array}$ & $\begin{array}{l}\text { Space organization of a } \\
\text { building, adequacy of } \\
\text { ventilation, space } \\
\text { characteristics and Floor } \\
\text { finishes were the major } \\
\text { structural housing attributes } \\
\text { that influences the preference } \\
\text { of house buyers choice in Joho } \\
\text { Bahru, Malaysia. }\end{array}$ \\
\hline $\begin{array}{l}\text { Tan, T.H. } \\
\text { (2012) }\end{array}$ & $\begin{array}{l}\text { Meeting First-time } \\
\text { buyers' Housing } \\
\text { Needs and } \\
\text { Preferences in } \\
\text { Greater Kuala } \\
\text { Lumpur Cities }\end{array}$ & $\begin{array}{l}\text {-Number of bedrooms } \\
\text {-Number of bathroom } \\
\text { - Size of living room } \\
\text {-Size of Kitchen } \\
\text { - Built-up area } \\
\text { - Green housing }\end{array}$ & $\begin{array}{l}\text { Number of bedroom is } \\
\text { considered very important by } \\
\text { first-time homebuyers. There } \\
\text { were insignificant relationships } \\
\text { in the preference to become a } \\
\text { homeowner based on number } \\
\text { of bathroom, size of living } \\
\text { room, built up area and kitcher } \\
\text { area. }\end{array}$ \\
\hline $\begin{array}{l}\text { Tan, T.H. } \\
\text { (2011) }\end{array}$ & $\begin{array}{l}\text { Measuring the } \\
\text { Willingness to Pay } \\
\text { for Houses } \\
\text { in a Sustainable } \\
\text { Neighborhood }\end{array}$ & $\begin{array}{l}\text {-Walls } \\
\text { - Flooring }\end{array}$ & $\begin{array}{l}\text { There are significant } \\
\text { relationships in the willingness } \\
\text { to pay based on structural } \\
\text { attributes that incorporate } \\
\text { environmental sustainability } \\
\text { such as floor and wall tiles }\end{array}$ \\
\hline
\end{tabular}

Furthermore, Tan (2011) studied the willingness to pay to changes in structural, locational, and neighborhood attributes of housing that incorporate sustainability objectives. A self-administered survey was conducted to collect the required data in Klang Valley, Malaysia. An ordinary least squares method together with a heteroscedasticity consistent covariance matrix estimator was used in analyzing the data. The results revealed significant relationships in the willingness to pay based on structural attributes that incorporate environmental sustainability such as floor and wall tiles. The summary of the different studies and the structural attributes investigated is presented in table 1 below.

From the foregoing structural attributes of residential property indeed impact on consumer's decisions and that the relative importance of various structural attributes in consumer's preferences varies across national contexts. Consumers of residential property are in two folds comprising buyer and renter/tenant. However, previous studies only examined the importance of various structural attributes to residential property consumers from the point of view of home buyers/owners and did not consider the perspective of renters/tenants. The importance of the various structural attributes to consumers may differ between buyers and tenants of residential property. Furthermore, residential property is made up of different 
categories; consequently, preferences for structural attributes may also vary across tenants occupying different categories of residential property. The residential properties in Ede town are in categories that are based on the number of rooms and supporting facilities provided in the apartments. This paper therefore intends to contribute to knowledge base by setting forth an understanding on the structural attributes that tenants (of different residential property categories) demand for in Ede, Nigeria with emphasis on the sizes of rooms and availability/sizes of other structural components.

\section{METHODOLOGY}

In order to evaluate tenant's demand for structural attributes in the residential properties, a self administered questionnaire survey was conducted to collect the required data directly from tenants. The target population for the study is tenants/renters occupying residential properties in Ede, Nigeria. This means that landlords or owners who occupy their residential properties within the study area were not eligible to participate in the study. Hence, to ensure the eligibility of respondents, stratified sampling was employed. A comprehensive list of the respondents (tenants) is not available to the researchers; therefore, samples were selected from five major areas of the town namely: Okegada, Agip, Allahu lateef, Ya salam and Country home. Furthermore, residential properties in the study area are in different categories. However, Dabara et al. (2018) observed that the dominant categories comprised tenement; one room self-contained, a room and parlour self-contained, two and three bedroom flats respectively. Only these categories were considered in this study. The choice of these categories was based on preliminary investigation which revealed that they are the major rented apartments with their demands being more frequent and stable in the study area. Consequently, other category such as duplex was excluded from this study and this could be one of the limitations of this study.

In line with sample size suggested in Cochran (1977) for infinite population (taking $95 \%$ confidence level with $\pm 5 \%$ precision), a total of 400 questionnaires were distributed, out of which 278 were returned representing $69.5 \%$ response rate. The data requirements for this study include among others the structural attributes available in the residential property and their sizes; the structural attributes (and /or attribute's size) that the tenant desires; and the tenant's willingness to pay more for the desired attribute(s). In order to determine the responsiveness of willingness to pay for desired attributes (or attribute size), the study hypothesized that $90 \%$ of the respondents in each property category would express willingness to pay more for the desired attributes or attribute size. This percentage which is based on the acceptable statistical range for a viable analysis would justify tenants' demand and motivate investors to improve the structural attributes in residential properties in the study area. The structural attributes used for the study include: the size of living rooms and bedrooms, size of toilet and bathrooms, size of kitchen, size of dining, size of storage room, type of floor finishes, perimeter fence and private backyard (the selection of these structural attributes among others was based on preliminary investigation which revealed that they are the major consideration in the study area. Hence, other structural attributes such as level of interior and exterior decorations, quality of building materials etc were excluded from this particular study even though they are also important structural attributes). 
Data collected were analysed using both descriptive and inferential statistical tools such as percentile, bar charts, weighted mean score and Chi square. A 5-point response scale and weighted mean score were used to determine the importance of each of the selected structural attributes to respondents if they were to make a decision to rent a residential property. Chi square was employed to test the responsiveness of willingness to pay. It specifically tests whether there is significant difference between the observed "willingness to pay" response by the tenants and the hypothesized proportion. Another limitation of this study is it focused on tenant's willingness to pay for desired structural attributes and did not consider how much more the tenants were willing to pay (even though it a very important factor that can justify investors incorporating the desired structural attributes in the property designs).

The various residential property categories and the number sampled are presented in table 2 below. Tenement comprises single rooms with shared toilet and kitchen facilities; a room self-contained is a room which has toilet and kitchen facilities attached; a room and parlour self-contained on the other hand comprised a bedroom and living room attached with kitchen and toilet facilities; two and three bedroom flats have two and three bedrooms respectively attached with kitchen, dining, toilet facilities and in some cases storage room.

Table 2: Types of Residential Properties and the Number Sampled in Ede, Nigeria

\begin{tabular}{lll}
\hline Types & No. of Properties & Percentage \\
\hline Tenement & 125 & 45.0 \\
A room self-contained & 14 & 05.0 \\
A Room and parlour self-contained & 23 & 08.3 \\
Two bedroom flat & 28 & 10.0 \\
Three bedroom flat & 88 & 31.7 \\
Total & 278 & 100 \\
\hline
\end{tabular}

Source: Field survey 2018

\section{DATA ANALYSIS AND DISCUSSION OF RESULT}

This section presented the data analysis and discussed the results pertaining to the study objectives starting with the sizes of the various structural attributes in the residential property categories.

Table 3: Average Sizes (in $\mathrm{M}^{2}$ ) of Structural Attributes in Residential Properties

\begin{tabular}{llllll}
\hline $\begin{array}{l}\text { Structural } \\
\text { Attributes }\end{array}$ & Tenement & $\begin{array}{l}\text { A room self- } \\
\text { contained }\end{array}$ & $\begin{array}{l}\text { Room/parlour } \\
\text { self-contained }\end{array}$ & $\begin{array}{l}\text { Two bed } \\
\text { room flat }\end{array}$ & $\begin{array}{l}\text { Three bed } \\
\text { room flat }\end{array}$ \\
\hline Living room & N/A* & N/A* & 9.50 & 12.25 & 14.00 \\
Bedroom & 6.25 & 6.25 & 6.25 & 6.25 & 6.25 \\
Bathroom & 1.50 & 1.50 & 1.50 & 1.50 & 1.50 \\
Dining & N/A* & N/A* & N/A* & 3.00 & 3.00 \\
Kitchen & 3.00 & 1.50 & 3.00 & 3.00 & 3.00 \\
Storage room & N/A* & N/A* & N/A* & 1.50 & 1.50 \\
\hline
\end{tabular}

Source: Field survey 2018

$N / A^{*}$ (the design does not incorporate the structural attribute)

From table 3 above, analysis of the sizes of structural components in the residential properties shows the average size of bedroom and bathroom is approximately 6.25 square meters and 1.50 square meters respectively for all categories of residential 
property understudied. Also, the approximate average size of living room is 9.50 square meters in a room and parlour self-contained; 12.25 square meters in two bedroom flats and 14.00 square meters in three bedroom flats. Findings further revealed that the average size of storage room is approximately 1.50 square meters in the flats. The study also found that only about $9.48 \%$ of the flats sampled have storage room facility implying that most of the residential properties in the study area were not provided with storage room.

Table 4 shows the types of floor finish in the residential property categories in the study area. The popular floor finishes in the property is either of ceramic tiles or of concrete (generally referred to as cemented floor). In the three bedroom flats category, $3.4 \%$ of the properties has fully tiled floor, $38.6 \%$ has every other area tiled except the bedrooms (which has concrete floor); $45.5 \%$ has only the bathroom tiled while all other area has concrete floor; and $12.5 \%$ has fully concrete floor. In the two bedroom flats category, $10.7 \%$ of the properties has fully tiled floor; $50 \%$ has every other area tiled except the bedrooms (which has concrete floor); and $39.3 \%$ has only the bathroom tiled while all other area has concrete floor.

Table 4: Types of Floor Finishes in the Residential Properties (\% in parenthesis)

\begin{tabular}{llllll}
\hline Types & Tenement & $\begin{array}{l}\text { A Room self- } \\
\text { contained }\end{array}$ & $\begin{array}{l}\text { Room/ } \\
\text { parlour self- } \\
\text { contained }\end{array}$ & $\begin{array}{l}\text { Two Bed } \\
\text { room flat }\end{array}$ & $\begin{array}{l}\text { Three bed } \\
\text { room flat }\end{array}$ \\
\hline Fully tiled & $0(0.0)$ & $8(57.1)$ & $4(17.4)$ & $3(10.7)$ & $3(3.4)$ \\
Fully tiled except bedrooms & $0(0.0)$ & $0(0.0)$ & $14(60.8)$ & $14(50.0)$ & $34(38.6)$ \\
Fully cemented except bath & $7(5.6)$ & $6(42.9)$ & $5(21.7)$ & $11(39.3)$ & $40(45.5)$ \\
Fully cemented & $118(94.4)$ & $0(0.0)$ & $0(0.0)$ & $0(0.0)$ & $11(12.5)$ \\
Total & $125(100)$ & $14(100)$ & $23(100)$ & $28(100)$ & $88(100)$ \\
\hline
\end{tabular}

Source: Field survey 2018

For a room and parlour self-contained, $17.4 \%$ of the properties has fully tiled floor, $60.8 \%$ has every other area tiled except the bedrooms (which has concrete floor), $21.7 \%$ has only the bathroom tiled while all other area has concrete floor. In a room self-contained category, $57.1 \%$ of the properties has fully tiled floor; $42.9 \%$ has only the bathroom tiled while all other area has concrete floor. In tenement property category, $94.4 \%$ has fully concrete floor while $5.6 \%$ has only the bathroom tiled with concrete floor in all other area. The above findings coupled with the tenants' earlier ranking of these attributes bring to mind the question of whether these structural attributes meet the expectations of the tenants. If otherwise, what do tenants actually desire in terms of structural components of residential properties in the study area?

The importance of the various structural attributes to tenants when making decision on renting residential properties is presented in table 5 above. The analysis showed that among the structural attributes listed, the presence of perimeter fence rank highest across four residential property types: a room selfcontained (mean score $=4.36$ ); room and parlour self-contained (mean score $=$ 4.21); two bedroom flat (mean score $=4.64$ ); and three bedroom flat (mean score $=4.54$ ). Beyond perimeter fence, other structural attributes such as type of floor finish, all en-suite bedrooms, size of bedrooms, size of living room, size of kitchen and size of storage room ranked among the first six important attributes (although with varying positions) across four categories of residential property. For example, all en-suite bedrooms ranked second in two bedroom flats and third in three 
bedroom flats. Size of bedrooms on the other hand ranked first in tenement room (mean score $=4.03$ ); second in one room self-contained (mean score $=4.28$ ); third in room and parlour self-contained (mean score $=3.82$ ); and fourth in two bedroom flats (mean score $=4.21$ ) and three bedroom flats (mean score $=4.21$ ) respectively.

Table 5: Tenants' ranking of Structural Attributes in Residential Properties in Ede

\begin{tabular}{|c|c|c|c|c|c|}
\hline Structural Attributes & $\begin{array}{l}\text { Tenement } \\
\text { rooms }\end{array}$ & $\begin{array}{l}\text { Weighted } \\
\text { A room self- } \\
\text { contained }\end{array}$ & $\begin{array}{l}\text { Mean Score } \\
\text { A room and } \\
\text { parlour self- } \\
\text { contained }\end{array}$ & $\begin{array}{l}\text { Two bedroom } \\
\text { flat }\end{array}$ & $\begin{array}{l}\text { Three } \\
\text { bedroom } \\
\text { flat }\end{array}$ \\
\hline Size of Living room & $N / A^{*}$ & $N / A^{*}$ & $3.74 \quad\left(5^{\text {th }}\right)$ & $3.82 \quad\left(5^{\text {th }}\right)$ & $4.18\left(5^{\text {th }}\right)$ \\
\hline Size of Bedroom & $4.03\left(1^{\text {st }}\right)$ & $4.28\left(2^{\text {nd }}\right)$ & $3.82\left(3^{\text {rd }}\right)$ & $4.21 \quad\left(4^{\text {th }}\right)$ & $4.21 \quad\left(4^{\text {th }}\right)$ \\
\hline Size of Bathroom & $2.14 \quad\left(5^{\text {th }}\right)$ & $3.07 \quad\left(6^{\text {th }}\right)$ & $2.65\left(8^{\text {th }}\right)$ & 3.29 & $3.43\left(8^{\text {th }}\right)$ \\
\hline Size of Dining & $\mathrm{N} / \mathrm{A}^{*}$ & $\mathrm{~N} / \mathrm{A}^{*}$ & $2.43 \quad\left(9^{\text {th }}\right)$ & 2.96 & $3.01\left(10^{\text {th }}\right)$ \\
\hline Size of Kitchen & $2.22\left(4^{\text {th }}\right)$ & $3.21\left(5^{\text {th }}\right)$ & $3.48\left(6^{\text {th }}\right)$ & 3.79 & $3.84\left(6^{\text {th }}\right)$ \\
\hline Size of Storage room & $N / A^{*}$ & $3.21 \quad\left(5^{\text {th }}\right)$ & $3.74\left(4^{\text {th }}\right)$ & 3.79 & $3.78\left(7^{\text {th }}\right)$ \\
\hline Floor finish & $2.32\left(2^{\text {nd }}\right)$ & 3.78 (3rd) & $4.17 \quad\left(2^{\text {nd }}\right)$ & 4.35 & $4.41\left(2^{\text {nd }}\right)$ \\
\hline All en-suite bedroom: & $N / A^{*}$ & $N / A^{* *}$ & $N / A^{* *}$ & $\left(2^{\text {nd }}\right)$ & $4.32\left(3^{\mathrm{rd}}\right)$ \\
\hline Perimeter Fence & $2.31\left(3^{r d}\right)$ & $4.36\left(1^{\text {st }}\right)$ & $4.21 \quad\left(1^{\mathrm{st}}\right)$ & 4.64 & $4.45 \quad\left(1^{\text {st }}\right)$ \\
\hline Private backyard & $\mathrm{N} / \mathrm{A}^{*}$ & $3.71\left(4^{\text {th }}\right)$ & $3.43\left(7^{\text {th }}\right)$ & 3.21 & $3.26\left(9^{\text {th }}\right)$ \\
\hline
\end{tabular}

This finding is in conformity with the findings in Opoku and Abdul-Muhmin (2010). Moreover, size of dining, private backyard and size of bathroom were the three least ranked structural attributes. Although their ranks also differ across the property categories, it generally suggests that these structural attributes were considered less important by tenants in the study area. Furthermore, the tenement category presented a peculiar outcome in the analysis in table 2 above. In this category, the size of bedroom ranked highest with mean score of 4.03 while much lower mean scores were observed for other structural attributes. For example, type of floor finish and perimeter fence that ranked second and third in that category have mean scores of 2.32 and 2.31 respectively. This margin could suggest that tenants in the tenement category considered size of bedroom as very important while other structural attributes such as floor finish, perimeter fence and size of kitchen were considered as less important. The implication of this finding is that the importance of the selected structural attributes varies across tenants of different categories of residential property.

The structural attributes that tenants expressed willingness to more for are presented in table 6 . It can be seen from the table 6 that tenants across the five categories of residential properties in the study area expressed willingness to pay more for larger bedrooms. This is suggested by $62.4 \%, 50.0 \%, 60.9 \%, 57.1 \%$ and $62.5 \%$ in tenement, a room self-contained, room and parlour self-contained, two bedroom flat and three bedroom flat respectively.

Other structural attributes that tenants across all categories expressed willingness to pay more for include fully tiled floor, perimeter fence and larger living room, larger dining, all en-suite bedrooms and private backyard where applicable. Beyond that, respondents in some property categories also expressed willingness 
to pay more for other structural attributes such as larger bathroom, larger kitchen and larger storage room. This finding is consistent with Buys et al. (2005); Sitar and Krajnc (2008); Anthony (2012); Okorie (2015).

Table 6: Structural Attributes that Tenant would pay more for (\% in parenthesis)

\begin{tabular}{llllll}
\hline Structural Attributes & Tenement & $\begin{array}{l}\text { A room self- } \\
\text { contained }\end{array}$ & $\begin{array}{l}\text { A room and } \\
\text { parlour self- } \\
\text { contained }\end{array}$ & $\begin{array}{l}\text { Two } \\
\text { bedroom } \\
\text { flat }\end{array}$ & $\begin{array}{l}\text { Three } \\
\text { bedroom } \\
\text { flat }\end{array}$ \\
\hline Larger Living room & $\mathrm{N} / \mathrm{A}^{*}$ & $\mathrm{~N}^{*} \mathrm{~A}^{*}$ & $04(17.4)$ & $08(28.6)$ & $20(22.7)$ \\
Larger Bedroom & $78(62.4)$ & $07(50.0)$ & $14(60.9)$ & $16(57.1)$ & $55(62.5)$ \\
Larger Bathroom & $00(0.0)$ & $02(14.3)$ & $06(26.1)$ & $12(42.6)$ & $26(29.5)$ \\
Larger Dining & $\mathrm{N} / \mathrm{A}^{*}$ & $\mathrm{~N}^{*}$ & $02(08.7)$ & $04(14.3)$ & $21(23.9)$ \\
Larger Kitchen & $00(0.0)$ & $03(21.4)$ & $05(21.7)$ & $07(25.0)$ & $32(36.4)$ \\
Larger Storage room & $\mathrm{N} / \mathrm{A}^{*}$ & $00(0.0)$ & $09(39.1)$ & $15(53.6)$ & $54(61.4)$ \\
Fully Tiled floor & $16(12.8)$ & $10(71.4)$ & $16(69.6)$ & $17(60.7)$ & $56(63.6)$ \\
All en-suite bedrooms & $\mathrm{N} / \mathrm{A}^{*}$ & $\mathrm{~N} / \mathrm{A}^{* *}$ & $\mathrm{~N} / \mathrm{A}^{* *}$ & $19(67.9)$ & $57(64.8)$ \\
Perimeter fence & $05(04.0)$ & $09(64.3)$ & $14(60.9)$ & $18(64.3)$ & $58(65.9)$ \\
Private backyard & $\mathrm{N} / \mathrm{A}^{*}$ & $02(14.3)$ & $05(21.7)$ & $15(53.6)$ & $54(61.4)$ \\
\hline Source:Fing
\end{tabular}

Source: Field survey 2018

$N / A^{*}$ (the design does not incorporate the structural attribute)

$N / A^{* *}$ (the structural attribute is fundamental in the design)

The structural attributes which some tenants did not express willingness to pay for include larger bathroom and kitchen in tenement category as well larger storage room in a room self-contained category. This response may not be unconnected to the design nature of the affected categories. Tenement accommodation is multitenanted with shared facilities while a room self-contained is usually occupied by an individual especially students or persons awaiting gainful or better employment hence the occupants give little or no consideration to the amount of space provided for the identified structural attributes in these categories.

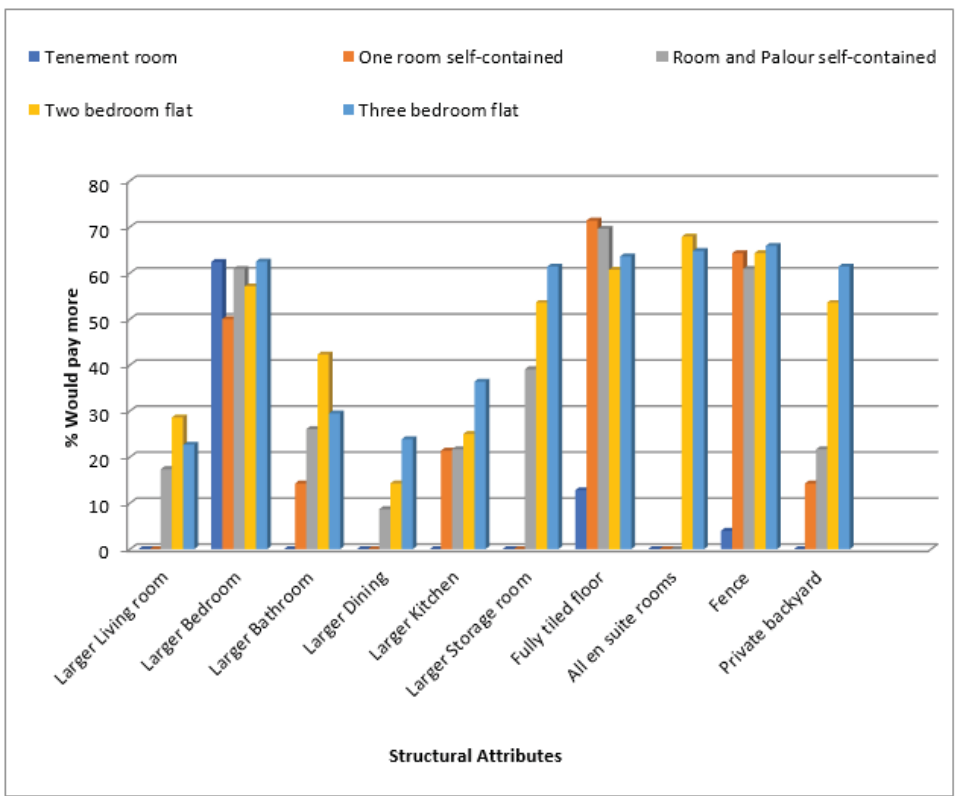

Fig. 1: Structural Attributes that Tenant would pay more for (by Property Categories)

Furthermore, the result of the analysis in table 6 above is represented in figure 1 below. It can be seen that among the selected structural attributes, larger bedroom was ranked very highly in terms of overall "would pay more for" by respondents in 
all categories of residential property. Beyond that, other structural attributes that were ranked very highly include fully tiled floor and fence (in a room self contained, room and parlour self contained, two and three bedroom flats); and all en-suite rooms (in two and three bedroom flat). Larger storage room and private backyard were also ranked highly in two and three bedroom flats.

Chi-square was employed to statistically test whether $90 \%$ of the tenants expressed willingness to pay more for their desired structural attributes. It specifically tests whether there is significant difference between the observed "willingness to pay" response by the tenants and the $90 \%$ hypothesized proportion.

Table 7: Chi-Square Test for $\mathbf{9 0 \%}$ of Tenants Would Pay More for Desired Attribute (pvalue in parenthesis)

\begin{tabular}{|c|c|c|c|c|c|}
\hline $\begin{array}{l}\text { Structural } \\
\text { Attributes }\end{array}$ & Tenement & $\begin{array}{l}\text { A room self- } \\
\text { contained }\end{array}$ & $\begin{array}{l}\text { A room and } \\
\text { parlour self- } \\
\text { contained }\end{array}$ & $\begin{array}{l}\text { Two } \\
\text { bedroom } \\
\text { flat }\end{array}$ & $\begin{array}{l}\text { Three } \\
\text { bedroom fla }\end{array}$ \\
\hline Larger Living room & $N / A^{*}$ & $\mathrm{~N} / \mathrm{A}^{*}$ & $134.73(.000)$ & $117.39(.000)$ & $442.51(.000)$ \\
\hline Larger Bedroom & $105.79(.000)$ & $16.79(.000)$ & $21.69(.000)$ & $33.59(.000)$ & $73.94(.000)$ \\
\hline Larger Bathroom & $00(0.0)$ & $88.18(.000)$ & $104.39(.000)$ & $69.14(.000)$ & $357.37(.000)$ \\
\hline Larger Dining & $\mathrm{N} / \mathrm{A}^{*}$ & $N / A^{*}$ & $168.93(.000)$ & $178.35(.000)$ & $427.68(.000)$ \\
\hline Larger Kitchen & $00(0.0)$ & $73.14(.000)$ & $119.08(.000)$ & $131.44(.000)$ & $281.29(.000)$ \\
\hline $\begin{array}{l}\text { Larger Storage } \\
\text { room }\end{array}$ & $N / A^{*}$ & $00(0.0)$ & $66.13(.000)$ & $59.06(.000)$ & $80.18(.000)$ \\
\hline Fully Tiled Floor & $827.76(.000)$ & $5.36(.021)$ & $10.67(.001)$ & $80.02(.000)$ & $67.96(.000)$ \\
\hline Allen-suite $\mathrm{B} / \mathrm{room}$ & $N / A^{*}$ & $N / A^{* *}$ & $N / A^{* *}$ & $69.14(.000)$ & $62.23(.000)$ \\
\hline Perimeter fence & $1027.22(.000$ & $10.29(.001)$ & $21.69(.000)$ & $91.68(.000)$ & $56.75(.000)$ \\
\hline Private backyard & $\mathrm{N} / \mathrm{A}^{*}$ & $88.18(.000)$ & $119.08(.000)$ & $59.06(.000)$ & $3.13(.077)$ \\
\hline
\end{tabular}

The chi-square and $p$ values of tenant's responsiveness of willingness to pay more for the desired structural attributes are presented in Table 7. A p-value of $<.05$ suggests the difference between the observed responses and the expected proportions is statistically significant while $p$-value of $>.05$ suggests the difference is not statistically significant. From the analysis, all the structural attributes showed $p$-values of $<.05$ suggesting there is significant difference between the observed responses and the $90 \%$ expected proportions across all categories of the residential property. These results showed that the observed responses do not march well the expected proportions implying there is sufficient evidence to suggest that $90 \%$ of tenants did not express willingness to pay more for the desired structural attributes in the entire categories of residential property understudied.

\section{CONCLUSION}

The study examined tenant's demand for structural attributes in residential property in Ede, Nigeria. It specifically analyzed tenant's desire for some selected structural attributes in five residential property categories as well as the tenant's willingness to pay more for the desired attribute(s). The findings of the study suggested that the importance of the selected structural attributes varies across tenants of the various categories of residential property. The study further showed that larger bedroom was ranked very highly in terms of overall "would pay more for" by respondents in all categories of residential property. Other structural 
attributes that were ranked very highly include fully tiled floor and fence (in a room self contained, room and parlour self contained, two and three bedroom flats); and all en-suite rooms, larger storage room and private backyard (in two and three bedroom flats). However, the result of the chi square test showed there is significant difference between the observed "would pay more for" responses and the $90 \%$ expected proportions ( $p$-values < .05) across all categories of the residential property. Conclusively, $90 \%$ of the sampled tenants in all categories of residential property in Ede did not express willingness to pay more for desired structural attributes. This study particularly brings to fore the expectations and behavior of tenants in terms of structural attributes' demand in each on the selected categories of residential property in Ede property market. Consequently, investors in the residential property submarket should take cognizance of these when making decision on house design so as to have a product that appeals to tenant's expectations while ensuring maximization of return from the real estate investment.

\section{REFERENCES}

Al-Momani, A. H. (2000) 'Structuring Information on Residential Building: A Model of Preference', Engineering, Construction and Architecture Management, 7(2), pp.179-190.

Aluko, O. (2011) 'The Effects of Location and Neighborhood Attributes on Housing Values in Metropolitan Lagos', Ethiopian Journal of Environmental Studies and Management, 4(2), pp. 69-82.

Amenyah, I. D. and Fletcher, E. A. (2013) 'Factors Determining Residential Rental Prices', Asian Economic and Financial Review, 3(1), pp. 39-50

Anthony, O. A. (2012) 'Examination of the determinants of housing values in urban Ghana and Implications for Policy Makers', Journal of African Real Estate Research, 2(1), pp.58-85.

Buys, L., Barnett, K., Miller, E., and Bailey, C. (2005) 'Smart Housing and Social Sustainability: Learning from the Residents of Queensland's Research House', Australian Journal of Emerging Technology and Society, 3 (1), pp. 43 - 57.

Cochran, W. G. (1977) Sampling Techniques 3rd ed. New York: Wiley.

Dabara, I D; Okunola A S; Odewande A G and Okorie A (2012a) Assessment of the rental values of residential properties in urban slums: the case of Osogbo, Osun State Nigeria In: Laryea, S., Agyepong, S., Leiringer, R. and Hughes, W. (Eds) Procs 4th West Africa Built Environment Research (WABER) Conference, Abuja, 24-26 July 2012, pp. 1-7.

Dabara, I.D., Olatoye, O.and Okorie, A. (2012b) 'An Examination of the Tenancy Agreement as a Shield in Property Management in Nigeria', International Journal of Business Administration, 3(4), pp. 54-66. Available online at http://www.sciedu.ca/journal/index.php/ijba/article/view/1474/725

Dabara, D. I. Omotehinshe, O. J. Uwaezuoke, I. N. Soladoye, J. O. and Chiwuzie, A. (2018) 'Building Material Prices and the Rental Values of Residential Properties in Ede, Nigeria', Proceedings of the 18th African Real Estate Society (AFRES) Annual Conference, Abeokuta, Nigeria, 11th -15th September 2018, pp. 213-233

Gibler, K. M., \& Nelson, S. L. (2003) 'Consumer Behaviour Applications to Real Estate Education', Journal of Real Estate Practice and Education, 6(1), pp. 63-83. 
Hurtubia, R., Gallay, O. and Bierlaire, M. (2010) 'Attributes of Households, Locations and Real- Estate Markets for Land use Modeling. Sustain City working paper, 21, Lausanne.

Nishani, W. (2016) 'Determinants of Rental Value for Residential Properties: A Land Owner's Perspective for Boarding Homes', Built-environment: Sri Lanka Research Journal of the Sri Lanka Institute of Architects, 12(1), pp. 10-22

Odame, W. K. A. (2010) 'Residential Market Development in Sub-Saharan Africa', International Journal of Housing Markets and Analysis, 3(4), pp.308-326

Okorie, A. (2015). 'Housing infrastructural facilities as Determinants of Rental Values of Residential Properties in Osogbo, Osun State Nigeria', Journal of Research in Business Economics and Management (JBREM), 1(1), pp.7-14

Olayinka C. O., Funsho R. S. and Ayotunde F. A. (2013) 'An Examination of the Factors Affecting Residential Property Values in Magodo Neighbourhood, Lagos State', International Journal of Economy, Management and Social Sciences 2(8), pp.639643

Opoku, R. A. and Abdul-Muhmin, A. G. (2010) 'Housing preferences and attribute importance among low-income consumers in Saudi Arabia', Habitat International 34, pp. 219-227

Sitar M. and Krajnc, K. (2008) 'Sustainable Housing Renewal', American Journal of Applied Sciences, 5(10), pp.61- 66

Tan, T.H. (2011) 'Measuring the Willingness to Pay for Houses in a Sustainable Neighborhood' International Journal of Environmental, Cultural, Economic and Social Sustainability, 7, pp.1-12

Tan, T.H. (2012). 'Meeting First-time buyers' Housing Needs and Preferences in Greater Kuala Lumpur Cities', Elsevier, 29(1), pp.389-396

Usman, M. (2016) 'Impact of Housing Attributes of Rental Values of Residential Properties in Minna, Nigeria', Unpublished M.Sc. thesis, Universiti Tun Hussein Onn Malaysia.

Vahid Moghimi Mahmud Bin Mohd Jusan (2015) 'Priority of Structural Housing Attribute Preferences: Identifying Customer Perception', International Journal of Housing Markets and Analysis, 8(1), pp.36 - 52.

Wilhelmsson, M. (2000) 'The Impact of Traffic Noise on the Values of Single-family Houses' Journal of Environmental Planning and Management, 43(6), pp.799-815

Yam, L. H. \& Ismail, M. (2008) 'Corporate Social Responsibility in Malaysia Housing Development House-buyers Perspectives', Proceeding of the 14th Pacific Rim Real Estate Society Conference, Kuala Lumpur 


\section{APPENDIX}

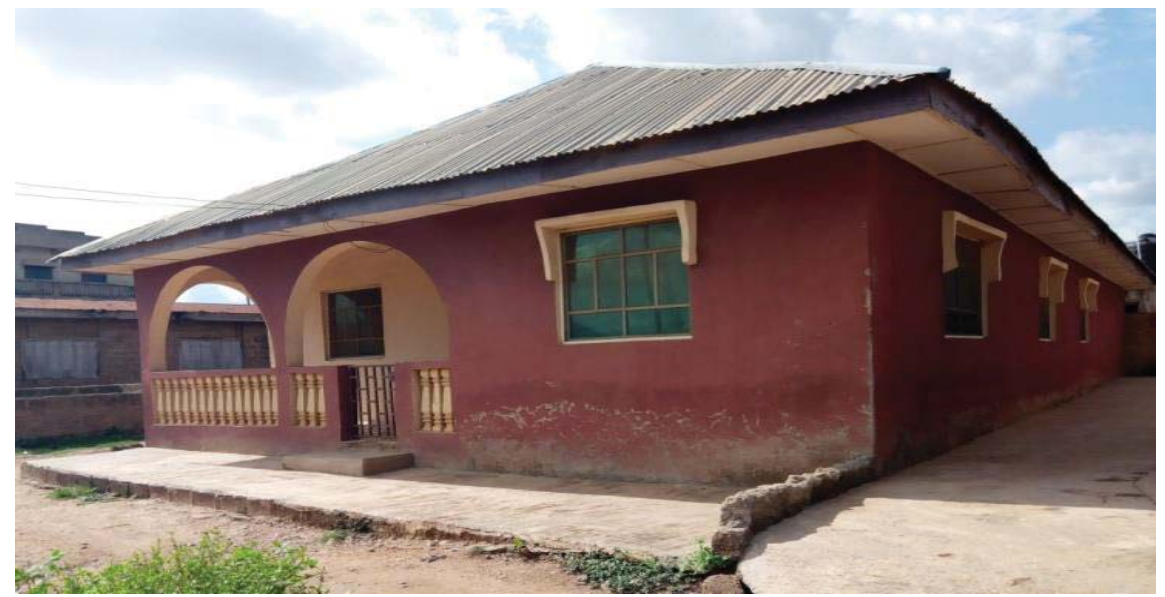

Fig 2: Tenement Residential Property

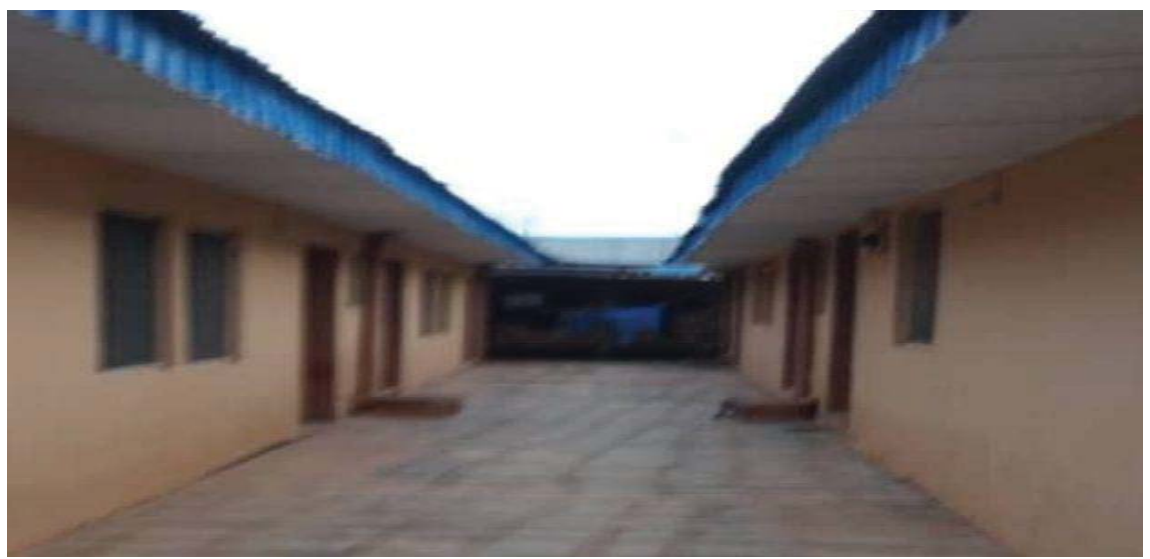

Fig 3: A Room Self-contained

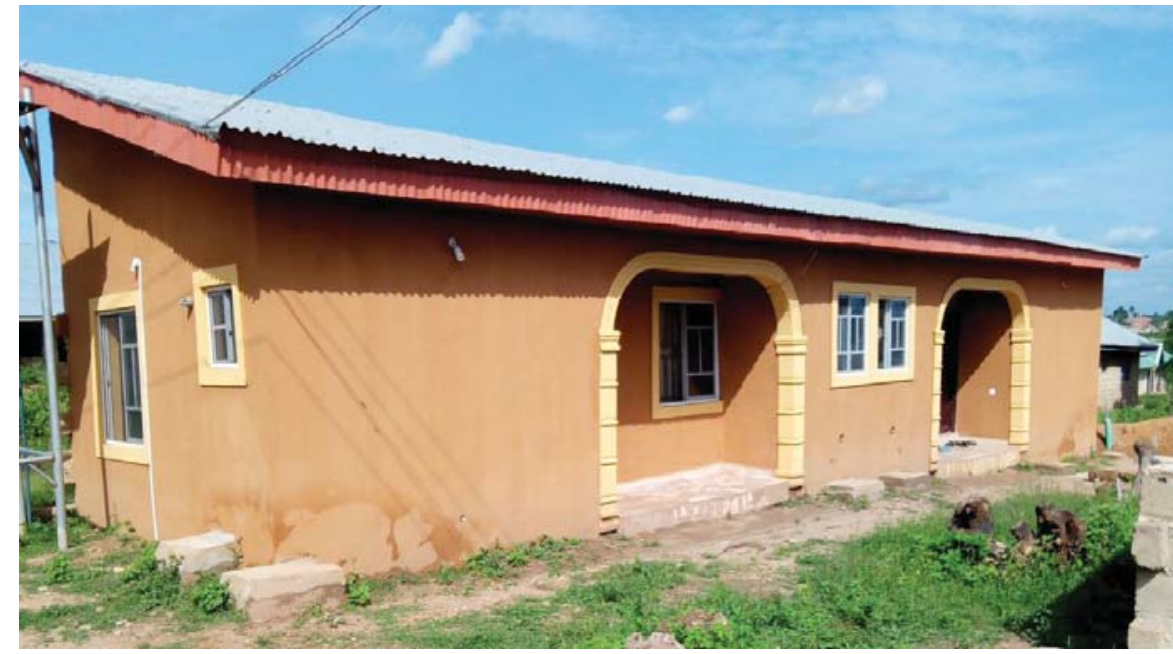

Fig 4: A Room and Parlour Self-contained (semi-detached) 


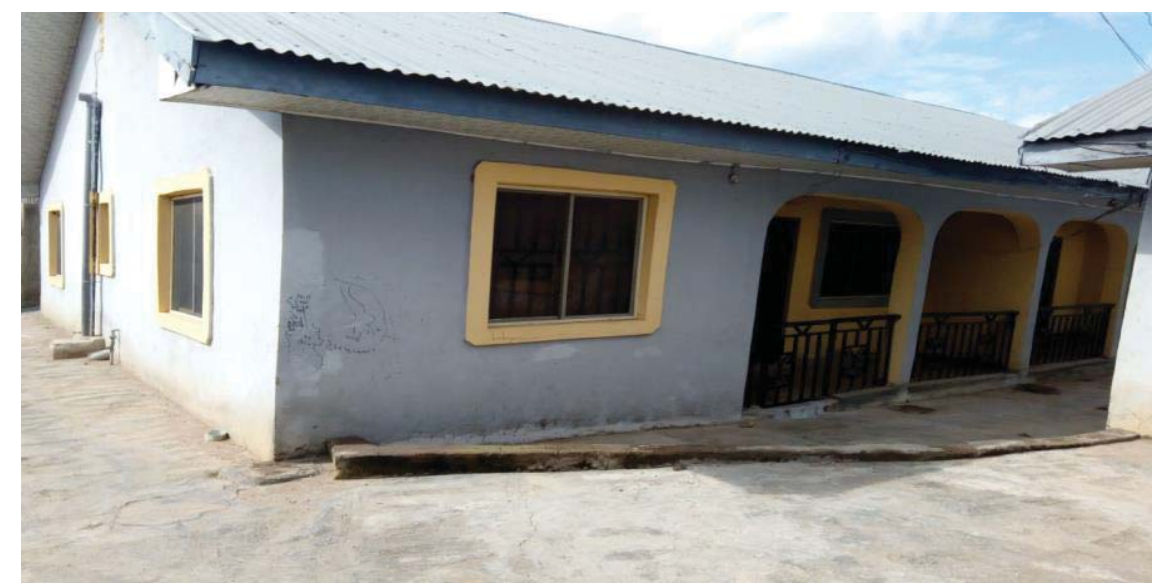

Fig. 5: Two Bedroom Flat

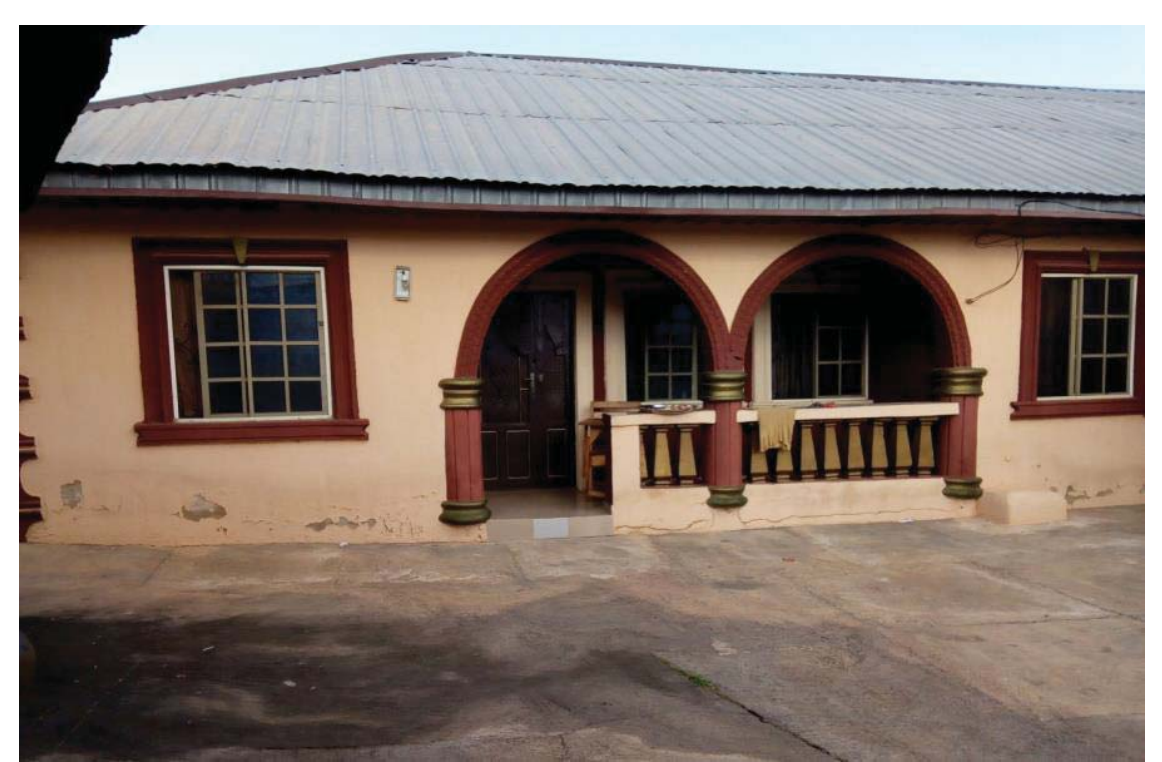

Fig. 6: Three Bedroom Flat 